\title{
Tourism Development Impact Toward Culture Changes in Globalization Era in Central Java
}

\author{
Sri Yuwanti \\ Pasca Sarjana \\ STIEPARI Semarang \\ Semarang, Indonesia \\ sriyuwanti@yahoo.com
}

\begin{abstract}
Tourism as source of foreign exchange and country's business opportunities for the community doesn't mean come without risks, especially in the sphere of local culture. On one hand tourism introduces the uniqueness of local culture. On the other hand, cultural tourism introduces the 'other' culture brought by foreign tourists, or the host country must provide tourist needs as required which give impact on local people's lifestyle changes. There could be problem if the changes affect the sustainability of local tradition or local uniqueness. This study attempts to explain the possibilities could occur when the doers and planners of tourism are less aware on cultural preservation and focus only on short term economic benefits by sacrificing the main core of the appeal. Some cases in recent tourism activities and events in Central Java are appointed and made as examples, then analyzed qualitatively with case study methods. Discussion of the results showed the 'tragedy of the common' and the tendency of travel catering that disgorge from the changes in tourist demand will affect the pattern of tourism services provision. However the benefit to the local culture will be in the form of new tradition born by a cross culture.
\end{abstract}

Keywords-tourism development, impact, culture conservation, Central Java

\section{INTRODUCTION}

Tourism is a sector where cultures between countries and locals meet and serves the acceleration of globalization process. In the process, there occure negative and positive impact of tourism in economy and social. The economic benefit has been the focus of recent studies and analyses, by which all tourism development programs are directed. On the contrary, the social impacts of the tourism development has been neglected, only few experts work especially on this matter. Meanwhile the impacts take place and secretly change the picture of tourism attractions in the country. The impacts, in fact, are worth to be studied and understood, for the benefits of the local culture. To see the possible process, a location will be studied as exemplar, and Central Java tourism activity is chosen.

Central Java is a province which rich with various culture and tourism activity that is related to culture events. The events usually consist of ceremony, local custom and tradition, art, and other cultural products include community daily life that is offered in the tourism activity based village (desa wisata). Tourism product in the form of local culture is more to attract the outsiders than the locals. Preference of program and performance are usually designed to serve the foreign or inbound tourists since they are supposed not familiar nor understand the product. It apply for the unique product and the icon of one local. However, the domestic from interlocals and the local domestic tourists, need to be concerned too for its larger number, and similarly, not yet familiar to the attraction object. Both groups have their own 'basic tourism needs' which will be the responsibility of local tourism institution to provide the needs in order to achieve the visitors' contentment.

The Central Java tourism uses a lot of cultural attractions as mayor drawcard for tourists aside of its natural attractions. Tourists visiting that area will get many different type of attractions. Some of the attractions that use cultural richness and wrapped in cultural event calendar of every district or city in example: Borobudur International Festival, Dieng Cultural Festival, Solo Batik Carnival, Grebeg Sekaten, Buka Luwur, etc. The events have been promoted months before or even years. In short, cultural events become popular since it involve the local peoples, either as cultures owner and doer or as event's committee.

\section{The PROBLEMS}

Problems of using traditional culture ceremonies or event for tourism attraction is the tendency to wrap it as commercial product, or made up the sacred ceremony or custom for cater visitors needs without concern on the local cultural value disposal. In fact, that is the local cultural or tradition which has been the source of the tourist attraction. One social implication of modernity in general is that tradition value might face an erosion, and then emerge a retraditionalization movement which use traditional signs for ceremonies. The ceremony is only made up to serve such needs, in the form of entertainment or showcase. Both will lessen the value of traditional culture and be the source of cultural retograde and decadent. The worst is when the event have been showed without the existent of the local community, the tradition owner, or has not involved them.

\section{A. Tourism development}

Tourism development activities usually are directed to dig potentialities, develop, promote, and put tourist attraction into market to be visited by domestic and foreign tourists. The potentialities consist of nature and culture. In many literatures on tourism development, there are many types of development 
such as on coastal tourism there are spontaneous, planned and localized, extensive, integrated, and catalytic development types with each sub types (Pearce, 1989). The tourism forms can be urban such as historic city, or rural form such as farm tour, and so on. the countrys group can be developed, developping, or under developped country (Pearce, 1989). In Indonesia, the development of tourism in one area will be related to the dimensions of economy, social culture, and ecology. (Damanik \& Weber, 2006). In the concept, culture places the tourists as the receiver of contact and cultural difference. They also have to appreciate the local people culture (Damanik \&Weber, 2006). It seems that the visitors or cultural outsider must be passive. On the other hand, in the service provider side, tourism must serve to intensify the cross culture communication between the locals and the outsiders. All of the local culture exhibitation must be accomodated in the form of attraction, access, and amenity, which in the same time must be able to conserve the heritages, traditions, and local wisdom too.

\section{B. Cultural changes factors}

Kuntowijoyo (1999) wrote that Indonesian culture always has two faces, a dichotomi, of centra/national and local, formally and deformally, tradition and modern, center and periphery, elite and grassroot, etc. When a tradition is no longer posed as a status social, then in the frame of national and local culture division, the local and traditional culture are treated as one part of pluralism, multiculturalism, multietnicity and material for cross culture comparison studies. Factors of cultural changes according to Kuntowijoyo (1999) are public taste, consumer and producer relation or market trend, and comercialization. The social implication of modernity, such as tradition value erosion, and then retraditionalization with the usage of traditional signs for ceremonies, which sometimes only a made up to serve such needs in the form of entertainment or showcase. Retraditionalization itself is as strong as the erosion of the traditional value and these bring the danger of cultural retograde and decadent.

\section{Strategy in facing cultural changes}

Abdullah (2015), supporting many views of experts on Indonesia, wrote that the country's community culture actually is a melting pot of many cultures brought by ancient or oldies visitors who enter the territory for many purposes. He argues that there is no authentic or genuine culture, and the recent is a product of cultural changes that occure through time dialog and acceptance. There are many different culture from outside that penetrated to people living and accounted as authentic as it is. In the same line, Arsuka (2015) mentions a new type of culture, a hybrid between a good old culture and a new or modern, called a cross culture, as a strategy in facing the dynamics cultural changes. In this paper this is taken as a mean for selecting the good and positive of outside culture and let out the bad and negative inside culture, to develop a new better culture in a free form and in freedom.

\section{METHOD}

Methods used for describing the fenomena and explaining the process is qualitative, using case study strategy. Data is collected through library research for the secendary information, by participating in the event, interviewing people, and observing some areas related to the study focus for the primary information. The location is Central Java, where many cultural events take place and are used for attract tourists. In this paper only four objects are observed, consist of a village of community based tourism and three events in various purposes. The flow of data collecting process and the thinking process is as shown in fig. 1 .

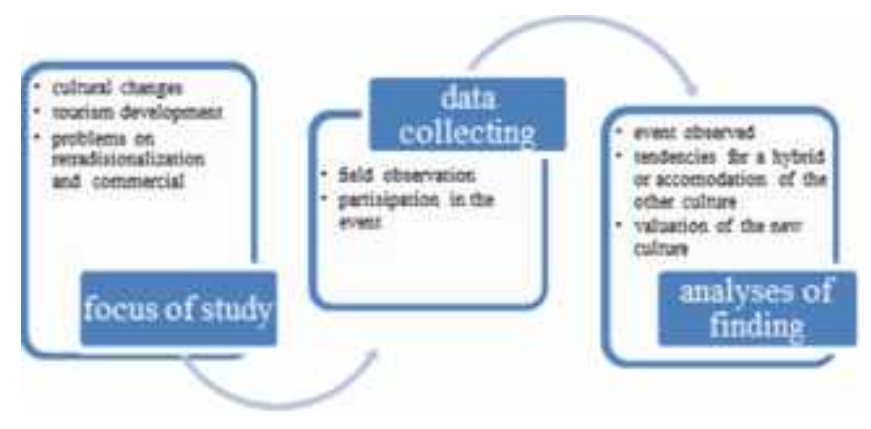

Fig. 1. Flow chart of research process

Various objects observed for its size of attention and type of visitors which is multinationalities or at least nationalwide. The object observed are chosen purposively based on the type of attraction. There are 4 (four) chosen objects: Borobudur International Festival (BIF), a cultural festival event participating by Budhism based religion countries such as India, Thailand, Japan, Korea, Vietnam, Cambodia, and other ASEAN related countries, Dieng Culture Festival (DCF), a cultural festival event on specific Javanese tradition, a ruwatan, a process to attemp to escape from disaster, Semarang Night Carnival (SNC), a street carnival event a show of the local Semarang on new cultural creativities by exploring their traditional culture, to give or find new meanings of the cultural attribute such as batik art and fashion, local culinary, local musics and dances, and one The findings is about the changes occured and the impact of the changes on the development of local culture. From the posible development, the tendency of formation toward new culture is then discussed. Poor village developed for community based tourism in Magelang regency, a tourism based village (TBV) Candirejo village, which is designed to give local people the opportunity for new employment related to tourism, and using local culture in the form of their usual daily life. Each object is presented on its objective, form of activities, people participation, type of visitors. Other elemens of change are presented in change factors table. The first to fourth factors are in the sphere of tourism development but the second and the fifth factors are also specially used for explaining the cultural changes. The change factors table shown as possibility, which is as an observation result. The selection of the factors analysed is based on the concept of cultural changes and its cause, which is related to tourism activities selected. 


\section{RESULT}

Based on Pearce (1989), in tourism development every activity will have different phases in development process in accordance to its based potentialities and local situation.. This means that what happen in one tourism area may be differ from what happen in other tourism area. In reality, the tourism industry has driven tourism product that must be counted economically and the sign of development is based on market demands. The Central Java tourism development program does in line with the common, as well as the central government policy on tourism. Some of the events designs, following the tourism definition and objectives of WTO and AIEST. The definitions have similarity in purposes or objectives of tourism which are economics driven such as to get the income, to increase devisa or local income, to expand the employment opportunity, to eliminate the poverty, and also to conserve natural environment. (Yoety, 2013)

From the secondary data there is information of the event/object, location, time table or calendar of events, and the purpose of the actuating of event or activities. In Indonesia, the tourism development objectives as stated in the Tourism Law no $10 / 2009$ is also to develop culture, increase the nation's prestige, to built nationalism and love and respect to the country, to strengthen the selfconsiousness and nation unity, and to increase peace and friendship among nations. One of the ethical code of tourism says that tourist shall respect the local value and tradition. And the local, in other hand, must respect the visitor, through offer hospitality and comprehend the visitors life style. There is no restriction, of cource, to the local community for not following the visitor life style, but to act respectfull and in harmony, and not to distort the local value. (Ethical Code of Tourism, Indonesian Tourism Ministry, without year dated :3).

The primary data from observation and people discussion, have given new insight on the result of the tourism development program in practices. All object studies have its own characteristic and the impact on local culture mostly enrich existing culture and/or educated viewer and tourism management. Enrich when the event bring a new insight and get along well with the tradition ar local culture. Educate when the event bring a new way of managing tourism development since the event itself is promoting the local culture or local traditions. Somehow, there are supporting and distracting views in people's opinion, but as culture itself is a product of negate among the member of society, if the majority agree to accept the changes, then it can be accomodated or listed as a new local culture but a hybrid one which will be traditional non autentic culture for the future generation.

From table 2, the data shows on the absent of possibility of cultural changes in BIF. It is caused by fact that the initiation of the event come from top down more than bottom up. That was the creative thinking of the top region's decision maker, a more government investment spending than gaining, and is functioned as promotion of the area's tourism potentialitis to foreign tourists. The economic multiplier effect of the event to the area is not directly go to the business of accomodation or access, but directly spread to the small businesses surrounding the place of event. The event is not designed as commercial but for promotion.

In the DCF, the 'yes/n possibility of cultural changes is caused by the massive modern culture involvement in the event, which local organizer and some of the local people involved actively in designing the itinerary, take part in the process in the field, and get the benefit of the event commercially. The danger is of retradionalization and distorsion of the local traditional culture authenticity, while a possible culture change occure is high in the younger generation and some progresive local official. Since they may know that the source of the benefit is the culture they may will still keep the exixtence of the culture and tradition, but mix it with new culture idea, in order to serve the different tourist segments, to attract them to join the festival.

TABLE I. THE OBJECTS STUDIED AND OBSERVED FOR DESCRIBING THE CULTURAL CHANGES

\begin{tabular}{|c|c|c|c|c|c|}
\hline The Object & $\begin{array}{l}\text { The } \\
\text { Objectives }\end{array}$ & $\begin{array}{l}\text { Type of } \\
\text { activities }\end{array}$ & $\begin{array}{l}\text { Type } \\
\text { of } \\
\text { visitors }\end{array}$ & $\begin{array}{l}\text { Visitors } \\
\text { and local } \\
\text { people } \\
\text { participat } \\
\text { ion }\end{array}$ & $\begin{array}{l}\text { Impact } \\
\text { on local } \\
\text { culure }\end{array}$ \\
\hline $\begin{array}{l}\text { Tourism } \\
\text { Based } \\
\text { Village } \\
\text { (TBV) } \\
\text { Candirejo, } \\
\text { Magelang } \\
\text { Regency. }\end{array}$ & $\begin{array}{l}\text { To improve } \\
\text { people } \\
\text { living } \\
\text { condition, } \\
\text { to } \\
\text { increase } \\
\text { income }\end{array}$ & $\begin{array}{l}\text { Experien } \\
\text { cing all } \\
\text { cultural } \\
\text { aspects } \\
\text { of village } \\
\text { life and } \\
\text { enjoying } \\
\text { local } \\
\text { uniquene } \\
\text { ss }\end{array}$ & $\begin{array}{l}\text { domesti } \\
\text { cs } \\
\text { foreigne } \\
\text { rs }\end{array}$ & $\begin{array}{l}\text { Visitor: } \\
\text { stay and } \\
\text { explore } \\
\text { the } \\
\text { village } \\
\text { life } \\
\text { Local: } \\
\text { function } \\
\text { as } \\
\text { service } \\
\text { provider } \\
\text { s }\end{array}$ & Enrich \\
\hline $\begin{array}{l}\text { Event 1, } \\
\text { Borobudur } \\
\text { Internation } \\
\text { al Festival } \\
\text { (BIF) }\end{array}$ & $\begin{array}{l}\text { To } \\
\text { introduce } \\
\text { the temple } \\
\text { to the world } \\
\text { community/ } \\
\text { internationa } \\
1\end{array}$ & $\begin{array}{l}\text { Performi } \\
\text { ng art, all } \\
\text { participa } \\
\text { nt } \\
\text { countries } \\
\text { show } \\
\text { their } \\
\text { culture }\end{array}$ & $\begin{array}{l}\text { Locals } \\
\text { surround } \\
\text { ing the } \\
\text { temple. } \\
\text { Internati } \\
\text { onal } \\
\text { commun } \\
\text { ity. } \\
\text { participa } \\
\text { nt }\end{array}$ & $\begin{array}{l}\text { Visitors } \\
\text { as } \\
\text { perform } \\
\text { ers and } \\
\text { viewer } \\
\text { and } \\
\text { local } \\
\text { people } \\
\text { as } \\
\text { viewer }\end{array}$ & $\begin{array}{l}\text { Enrich, } \\
\text { Educate, } \\
\text { Inform }\end{array}$ \\
\hline $\begin{array}{l}\text { Event } 2 \\
\text { Semarang } \\
\text { Night } \\
\text { Carnival } \\
\text { (SNC) }\end{array}$ & $\begin{array}{l}\text { To } \\
\text { introduce } \\
\text { local } \\
\text { creativity } \\
\text { /contempor } \\
\text { er }\end{array}$ & $\begin{array}{l}\text { Carnival } \\
\text { at night } \\
\text { on the } \\
\text { city street }\end{array}$ & $\begin{array}{l}\text { Locals } \\
\text { and } \\
\text { foreigne } \\
\text { rs }\end{array}$ & $\begin{array}{l}\text { Visitor } \\
\text { and } \\
\text { locals as } \\
\text { viewer }\end{array}$ & Enrich \\
\hline $\begin{array}{l}\text { Event 3, } \\
\text { Dieng } \\
\text { Culture } \\
\text { Festival } \\
\text { (DCF) }\end{array}$ & $\begin{array}{l}\text { To } \\
\text { introduce } \\
\text { local } \\
\text { culture/ } \\
\text { unique, } \\
\text { specific }\end{array}$ & $\begin{array}{l}\text { Ceremon } \\
\text { y on local } \\
\text { tradition }\end{array}$ & $\begin{array}{l}\text { Local, } \\
\text { domesti } \\
\text { c } \\
\text { visitors, } \\
\text { and } \\
\text { foreigne } \\
\text { rs }\end{array}$ & $\begin{array}{l}\text { Locals } \\
\text { as } \\
\text { perform } \\
\text { er and } \\
\text { visitors } \\
\text { as } \\
\text { viewer. }\end{array}$ & Educate \\
\hline
\end{tabular}

The 'yes' possibility of the SNC and Candirejo TBV surely exist because the people organized themselve to do something new to sell their potentialities. The difference is that SNC is a modern way to show the cultural tradition, only a show on the street, no permanent selling and buying activity directly done 
on the carnival, while the Candirejo TBV do sell and try to keep their traditional lifestyle for commercial objectives, and organised permanent selling and buying activities. The sign of modernity in Candirejo is the development of needs to learn foreign languages, especially English and French, in order to serve the need of majority of visitors: the foreign tourists.

TABLE II. POSSIBLE CHANGE FACTORS

\begin{tabular}{|c|c|c|c|c|}
\hline Event & $\begin{array}{l}\text { Community } \\
\text { preference }\end{array}$ & $\begin{array}{l}\text { Market } \\
\text { driven }\end{array}$ & $\begin{array}{l}\text { Comm } \\
\text { ersial }\end{array}$ & Concept of cultural changes \\
\hline $\mathrm{BIF}$ & no & yes & no & $\begin{array}{l}\text { No sign of cultural } \\
\text { changes, only shows of } \\
\text { country participant's local } \\
\text { culture, mostly art, and the } \\
\text { local as the consumer. }\end{array}$ \\
\hline DCF & Yes/no & yes & yes & $\begin{array}{l}\text { Mix of traditional and } \\
\text { modern culture }\end{array}$ \\
\hline SNC & yes & yes & yes & $\begin{array}{l}\text { Modern creation of } \\
\text { traditional material }\end{array}$ \\
\hline $\begin{array}{l}\text { TBV } \\
\text { Candi } \\
\text { rejo }\end{array}$ & yes & yes & yes & $\begin{array}{l}\text { Defence to hold the local } \\
\text { authentic tradition for } \\
\text { cultural tourism market }\end{array}$ \\
\hline
\end{tabular}

The cultural elements as tourist attraction and the cultural changes caused by tourism activity: general frameworks for impact assessment

Most of the impact assessment of cultural based tourism is done within the economic sphere of the development process that already occured. The cultural product in tourism is posed as the end products to be consumed. This has impact to the traditional culture in the non economic framework, and the impact is development of new cultures, and the possible new cultural event to be developed as tourism product. This means that culture will end in the same position, will it be studied as economic product or social product, that is when it is posed as source for tourism.

Culture itself is teoretically the product of human living dynamic process, which always changes by time by generations. The dynamic process of human life is a form of survival for live, mostly for living, to fullfil the living needs. This also means that culture will change when the human living condition moves toward a new direction, modernization or globalization, or even just for dealing the small problem in living.The big shock like globaliztion and modernization will have big impact and bring tremendous changes to the community life, but the small shock like living need will be able to changes culture bit by bit. Related to tradition in the form of custom, ceremony to celebrate special day and many similar thing, will only be performed or done when the people have ability to do or perform. In this case, the most important ingredient is economic ability or knowledge about the important of the ceremony. Recent development of retraditionalization ( create a new tradition), may have reasons and it can be related to the driven such as economy for betterment of society living condition, or, knowledge that such old tradition has important meaning for the bettermen of society's social life. This thought bring to a realization that everything that is counted as traditional today was a modern and new thing in its old time, and the existence untill today becouse people or the owner still hold it for specific purpose. The other ingredient is the sense of ownership, sense of belonging of the tradition or local culture. When nobody of the spesific society know or have sense of ownership, the tradition surely will vanish or lost.

\section{A. The tragedy of the common in cultural event for tourism}

The other problem relate to the use of tradition and local culture for tourism is when the people of the other areas tend to follow one success example,or the best practise of one showcase, and try to do the same thing. It is known that culture has bordeline, Pigeaud draw the culture line of Java, and there are more than 10 areas differenciated in culture. Each has uniqueness but not all are suitable to be wrapped for tourist attraction. However, with the creativity of local people, eventhough only different in local language or local culinary, each area may show their tourist attraction based on that diferences. The problem occured when each area are copying each others, and every area try to attract visitors using the same theme of culture or tradition. The negative side of this is that only the best will be chosen. The positive side of this is that there are abundant source of similar cultural events and tourist may choose some that fill their prefernce, economicaly or socially, and the best one. As the uniqueness of the culture and nature is the strength of tourist attraction, when everywhere show the similar event, the decreasing visit may happen due to the visitor boredom. The question come up for the even organizer in the local related to which tradition will be choosen as local icon for tourist attraction, why, and how.

The penetration of modern or foreign culture through tourism activity on the local is real. That happens since the tourism activity is a form of the meeting of two different groups, the outsider and the insider of a locality. The possible changes occur when the insider willing to adopt or to like the culture brought by the outsider. The process can be called culture enrichment, or a creasion of new culture. Many experts may called it hybrid culture, but in fact, there might be no authentic culture to a country, that since the ancient time has become the sea port to be visited by many nations, like Indonesia.

The preference of new generation of people also have strong effect on the culture features, and form a new kind of cultural traditions and social customs. The global network that been developed through information technology and tourism have also rapidly change the young people idea and preference on almost every part of life. That is the nature of culture, however, to always develops and changes. When a community will to accept the new ideas and create a new culture, it can be a new art, tradition, and customs, or just a retraditionally using new idea on an old local culture. The negative part of retraditionalization is when this activity draw a harsh comment or conflict between parties involved, or the domination of the stronger to the weaker, or causing erosion on the value of local and traditional culture.

Tourism as a sphere for interaction among people, dialogues between communities, and meeting of various forms of cultures, can be used as a tool for evaluate the preference change on traditions and other local cultures. Tourism 
development, which uses culture and nature for its attractions and activities then must concern on the attraction design and program, for example on what to show and what to offer or on where to visit and whom to meet, to give a better program for visitors and a maximum protection for the most important culture or social investment that has been used for the activity. In one side, tourism development is directed to enrich people economically, but it shall not done by depriving local cultural richness to be a cultural uniformity or similarity, which means the culture showcase is not unique and may not attactive anymore. Consequently, to avoid the' tragedy of the common' in tourism development, the government shall prepare tool for selecting the unique culture and study the difference among the various local traditional cultures richness, before listing these to the cultural event calendar. Using that mindfully selection of cultural event for tourism showcase, the to be visitor will have a better direction on the events, and the local community will get the benefit of conserving their authentic local traditional culture, also to fully participate in the cultural event at their own place.

\section{CONCLUSION}

Globalization era has brought many possibilities on social transformation and economic development of many countries, including Indonesia and Central Java as one of Indonesia's province. One of the many possibilities is that social tranformation will affect culture as the form of human living and will go toward the changes as long as the community accept it as their preference or by market drives. Then, the new local culture is born. Tourism development, especially those which using culture as attraction is not the only actor for the culture changes occure, since the other sectors included in the development and benefited by globalization will also share the impact to the culture changes. The bad news is that tourism sector is a multi sector which has close relation to almost all sectors, so it can be the most responsible to the culture changes happen. Furthermore, tourism obviously have used traditional culture as the investment or asset of attractions. There is no valuation on impact of less or more, high or low, in the traditional culture used for tourism, but there is bad or good according to the owner, the doer, and the viewer. Basically, both are just the normative measurement.

\section{REFERENCES}

Abdullah,T. (2015). Dinamika Kebudayaan: Otentisitas dan Saling Penetrasi dalam Lintasan Sejarah, in Mauludi, S (ed), Penyerbukan Silang Antar Budaya Membangun Manusia Indonesia. Jakarta, Kompas Gramedia.

Arsuka, N.A. (2015). Tentang Penyerbukan Silang Antar Budaya: Sebuah Strategi Kebudayaan, in Mauludi, $S$ (ed), Penyerbukan Silang Antar Budaya Membangun Manusia Indonesia. Jakarta, Kompas Gramedia.

Creswell, J.W. (1998), Qualitative Inquiry and Research Design Choosing among Five Traditions. Sage Publication, London.

Damanik, J. \& Weber, H.F. (2006), Perencanaan Ekowisata, dari Teori ke Aplikasi, PUSPAR UGM, Yogyakarta.

Dinas Kebudayaan dan Pariwisata Provinsi Jawa Tengah.(2016), Jawa Tengah Calendar of Events, Semarang.

Kementrian Pariwisata (n.d) Kode Etik Kepariwisataan, Jakarta.

Koentjaraningrat.(2004), Kebudayaan Mentalitas dan Pembangunan, Gramedia Pustaka Utama, Jakarta.

Kuntowijoyo. (1999). Budaya dan Masyarakat, Tiara Wacana , Yogyakarta.

Pearce, D. (1989), 2nd ed, Tourist Development, Longman, London, UK.

Rukmana, A., \& Lembong, E. (2015). Penyerbukan Silang Antar Budaya, in Mauludi, $S$ (ed) Penyerbukan Silang Antar Budaya Membangun Manusia Indonesia ( pp xxxvix- lxiv). Jakarta, Kompas Gramedia.

Yoety, O.A. (2013). Komersialisasi Seni Budaya dalam Pariwisata. Bandung. Angkasa. 